$\operatorname{cocos}(1994-1995), 10,35-47$

Printed in Sri Lanka

\title{
ECONOMICS OF SOIL MOISTURE CONSERVATION IN COCONUT LANDS USING COCONUT HUSKS AND COIR DUST
}

\author{
P Abeygunawardena', F Abeyratne ${ }^{2}$ and M T N Fernando ${ }^{3}$ \\ Consultant Agricultural Economist, Coconut Research Instifute of Sri Lanka and Senior \\ Lecturer, Faculty of Agriculture, University of Peradeniya, Sri Lanka
}

2. United Nations Development Programme, 202 Bauddhaloka Mawatha, Colombo 7, Sri Lanka

3. Coconut Research Institute, Lunuwila, Sri Lanka

\begin{abstract}
Economic feasibility of soil moisture conservation in coconut production using coconut husks and coir dust was examined in this study. The preliminary data for the study were collected from two trials conducted by the CRI along with several other secondary information. The results of the analysis revvealed that calculated Benefit-Cost ratios and Net Present Values are financially and economically acceptable under all the scenarios addressed in this study. Three different interest rates, such as $10 \%, 15 \%, 18 \%$ and two effective time periods (viz. six and nine years) were used for the analysis. Based on the estimated economic parameters, it is concluded that the efforts on moisture conservation using coconut husks and coir dust in lateritic gravel and sandy soils are economically viable propositions. As the initial cost of investment is substantial, other means to overcome the problems of financial constraints in investment may be looked into.
\end{abstract}

\section{INTRODUCTION}

Soil moisture conservation and coconut yield are highly related and the adverse effects of moisture deficit are long lasting due to the perennial nature of the crop (Abeywardena, 1968; Peiris \& Peiris, 1991-1993). In the above two studies, (Abeywardena 1968; Peiris \& Peiris, 1991-1993) have estimated the functional relationship between rainfall and fluctuation of coconut yield. The estimated regression coefficients between rainfall and coconut yield were 0.93 and 0.89 respectively. Based on the information from the IRHO (Rognon and Delbosc, 1990), it is evidenced that in

1. Present Address: Office of the Environment, Asian Development Bank, 6 ADB Avenue, Mandaluyong, Metro Manila, P O Box 789, 0980 Manila. Philippines 
a prolong drought, reduction in every $100 \mathrm{~mm}$ of water reduces copra yield by $500 \mathrm{~kg}$ $\mathrm{ha}^{-1}$ year $^{-1}$. Although the cause and the effect between rainfall and coconut yield are well documented, the exact relationship or functional form between these two variables is much more complex.

Better understanding of this issue was a long felt need and a fair amount of work has already been done by the Coconut Research Institute (CRI) on this area. A partial review of related issues can be found in Liyanage et al., 1993. The CRI has conducted a series of trials to examine the impact of soil moisture conservation using coconut husks and coir dust on the yield of coconut. One such trial was conducted in lateritic gravel soils (Ultisols) of Ratmalagara Estate, Madampe (1981-1986) and another trial was conducted in sandy soils of Shantil Estate, Pallama (1982-1986).

The first experiment consisted of three treatments, (i) control (ii) husk in pits (iii) coir dust in pits. The second experiment consisted of five treatments, namely, (i) control (ii) husk in pits (iii) busk in trenches (iv) coir dust in pits and (v) coir dust in trenches. The latter experiment tested not only the effect of the material used but also the method of placement on the coconut yield. A summary of the findings of these trials is presented in Table 1.

Table 1. Summary of research findings of two trials on soil moisture conservation using coconut husks and coir dust

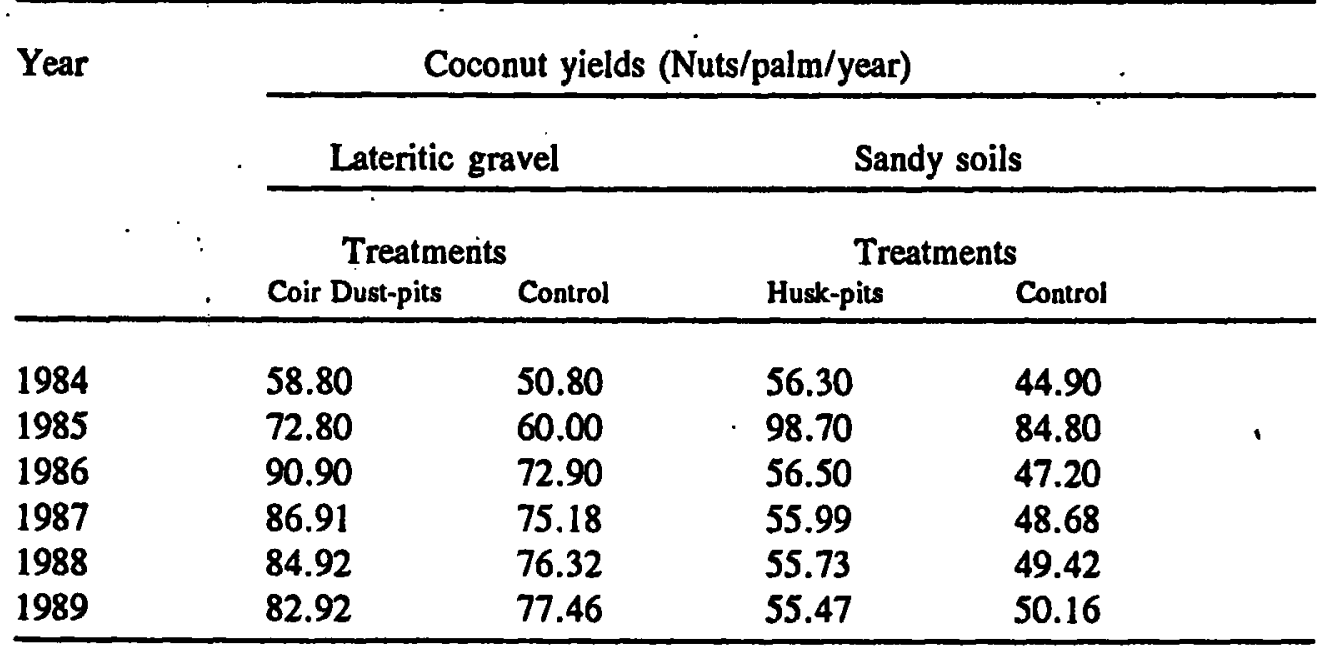

Based on the findings of the above trials, the CRI has recommended burying of coir dust in pits (particularly in lateritic gravel soils) and coconut husks in pits (particularly in sandy soils) to increase coconut yield (Anon, 1990). Therefore, the coconut producers are encouraged to adopt moisture conservation measures in their lands to obtain better yield from coconut palms.

\section{OBJECTIVES}

As clearly found from the trials conducted by the CRI, the yield improvements due 
to the moisture conservation efforts were substantial. The efforts on soil moisture conservation however, are not cost-free. The coconut producers have to incur a substantial cost to implement the recommendation of CRI. For example, besides the labour cost to open pits to place coconut husks and coir dust, coconut producers have to buy and transport these materials to their land if they are not readily available. If they are available in their land itself, they may not incur a direct cost for acquiring them, but they have to forego a certain income. That is because if coconut producers did not use these materials in their lands they might sell them and earn a portion of the income. Therefore, the objective of this study is to investigate the economic viability of CRI recommended moisture conservation methods in coconut lands. The specific objectives are to examine the economic viability of: (a) coir dust in pits in the lateritic gravel soils and (b) coconut husks in pits in sandy soils for moisture conservation in coconut lands.

\section{METHOD OF ANALYSIS}

In order to examine the economic viability of the moisture conservation methods recommended by the CRI, a broad framework of Benefit Cost analysis was adopted. Although large number of techniques could be used for such investigations [i.e. partial budgeting, internal rate of return, net present value (NPV), benefit cost ratio (B/C ratio) etc.] the latter two methods were selected in this study due to two reasons. They are: the simplicity of the approach and the possibility to convert monetary figures in different years into one time period. In other words, the methods adopted in this study allow the analyst to compute the benefits and costs as they occurred in specific time periods after making the necessary modifications and transformations. As the impact of soil moisture conservation on coconut yield is long lasting, such flexibility is very important. Thus these two approaches were thosen as suitable methods to analyze the data gathered for this study.

The NPV is simply the net present value of the cash flow of any investment. Here the effort on moisture conservation considered as an investment and additional yield increments were considered as returns to the investment. To calculate NPV, the following formula can be used.

$$
N P V=\sum_{t=1}^{n} \frac{B_{t}-C_{t}}{(1+r)^{t}} .
$$

Where,

$B_{2}=$ Yearly benefits (in this case incremental income only)

$C_{q}=$ Costs of moisture conservation effort in each year

$1 \quad=$ Number of years the impacts of moisture conservation effort lasts

r. = Discount rate 
Concept of NPV provides the financial aspects of moisture conservation effort on the overall basis, but it does not provide the returns to effort on unit rupee basis. In other words, it does not give an idea about how much eventually a coconut producer can earn in-turn, if he invests one rupee on moisture conservation activities. In order to provide such information, B/C ratio was also calculated for different types of moisture conservation activities. The formula to calculate the $\mathrm{B} / \mathrm{C}$ ratio is given as follows and all the notations are as defined earlier.

$$
\text { B/C ratio } \sum_{t=1}^{n} \frac{n}{C_{t} /(1+r)^{t}}
$$

\section{DATA}

The data for the analysis were obtained from several sources. Table 1 shows the information on nut yield for each year during the experimental period. These were obtained from the data that were collected for two experiments mentioned earlier (Liyanage et al., 1993). Cost data for making pits, burying husks or coir dust and covering them and internal transportation of husks or coir dust were collected from estate norms set by the Ratmalagara Estate for the experimental period. Information on price of husks and transportation costs (including labour) or materials were obtained through primary sources. For this, a sample of $\mathbf{2 0}$ mill owners was interviewed using a check list. Price of nuts was obtained from the records kept at the offices of two estates.

Experiments on moisture conservation efforts suggest that the yield improvements commence from third year after coconut husks are buried in the soils (Shanmugam, 1970). Then it continues to last about 5 years. However, the trials at the Ratmalagara and the Shantil estates indicate that the yield increments due to placement of coconut husks or coir dust in pits commenced, three and two years after adoption of husks in pits and coir dust in pits respectively. Further, the same trails showed that the beneficial effects continued to last six years, both in coconut husks in pits and coir dust in pits. Therefore, two analytical scenarios were developed to overcome the problem of differences in effective time period. The first scenario was therefore, based on six years effective time period and the second scenario nine years effective time period considered after burying coconut husks and coir dust.

In order to examine the financial viability of a project an average of $18 \%$ interest rate is generally used for small and medium term loans in Sri Lanka. Further, for economic evaluation of a project a $10 \%$ discount rate is often used by the National Planning Division of the Ministry of Planning and Plan Implementation. Therefore, in this analysis three discount rates namely $10 \%, 15 \%$ and $18 \%$ were used to convert benefits and costs in different time periods into one point of time to compare them. 
Tabje 2. Costs and incremental benefits of different moisture conservation measures

\begin{tabular}{|c|c|c|c|c|c|c|}
\hline \multirow[t]{3}{*}{ Year } & \multirow[t]{3}{*}{ Item } & \multicolumn{2}{|l|}{ Cost (Rs/ha) } & \multicolumn{3}{|c|}{ Incremental Benefit (Rs/ha) } \\
\hline & & Lateritic soil & Sandy soil & Lateritic soil & Sandy soil & \\
\hline & & Coir dust & Husk & Coir dust & Husk & \\
\hline $\begin{array}{l}1981^{*} \\
1982^{* *}\end{array}$ & $\begin{array}{l}\text { Cutting pits } \\
\text { Filling and closing of pits } \\
\text { Internal field transportation } \\
\text { Transportation up to field } \\
\text { Material cost } \\
\text { Labor - loading and unloading } \\
\text { of coconut husks }\end{array}$ & $\begin{array}{l}524: 40 \\
194.58 \\
405.72 \\
690.00 \\
-\end{array}$ & $\begin{array}{r}648.60 \\
292.56 \\
608.58 \\
1168.86 \\
1115.04 \\
1095.72\end{array}$ & $\cdot$ & & . \\
\hline $\begin{array}{l}1983 \\
1984 \\
1985 \\
1986 \\
1987 \\
1988 \\
1989\end{array}$ & 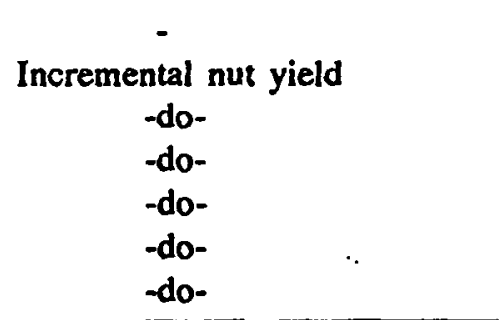 & $\begin{array}{l}33.12^{+\infty} \\
53.00 \\
74.52 \\
85.00 \\
62.32 \\
48.95\end{array}$ & $\begin{array}{l}46.00 \\
57.50 \\
38.49 \\
30.27 \\
26.13 \\
43.98\end{array}$ & $\begin{array}{l}3554.88 \\
2844.18 \\
3278.88 \\
3982.74 \\
4166.37 \\
1754.49\end{array}$ & $\begin{array}{l}5238.48 \\
2761.38 \\
1617.36 \\
2229.89 \\
3161.73 \\
1685.90\end{array}$ & \\
\hline
\end{tabular}

- investment cost in coir dust trial was committed in 1981

* investment cost in coconut husks trial was committed in 1982

costs of collection of incremental nut yield

incremental nut income

Note: Although there was a subsidy scheme for soil moisture conservation in coconut, commeneing from 1984, it is not included in this analysis. Because this scheme is no longer effective. 


\section{RESULTS AND DISCUSSION}

The formal selection criterion for the NPV measure of a project allows us finally to accept any project if a positive value for the decision criterion is obtained. $\mathrm{B} / \mathrm{C}$ ratio is greater than one means investment of one rupee in a particular project gives something more than one rupee in-turn of that investment. Therefore, it is also considered as economically acceptable because the investor makes more money than what he invested. In order to understand the magnitude of the investment and the incremental benefits, of the soil moisture conservation practices in coconut lands, using coconut husks and coir dust, investment requirements and the incremental benefits are presented in Table 2 in summarized form. Results of the calculated NPVs values and $\mathrm{BC}$ ratios are presented in Table 3 under different discount rates such as $10 \%, 15 \%$ and $18 \%$. Of first part of this study, all these costs and benefits have been looked at in terms of an individual coconut producer. Such analysis in the literature is identified as a financial analysis (Gittinger, 1982). As the CRI recommendations are directly aimed at the coconut producers, it is very important to understand the financial consequences from an individual point of view. Based on the financial analysis, it is clear that all the $\mathrm{B} / \mathrm{C}$ ratios are greater than one under different treatments and discount rates. The highest $\mathrm{B} / \mathrm{C}$ ratio is 5.85 at $10 \%$ interest rate and it is obtained using coir dust pits in lateritic soils. This indicates that if a coconut producer invests one rupee on burying coir dust in lateritic soils he could earn 5.85 in-turns of that investment. The lowest B/C ratio is 1.77 at $18 \%$ interest rate and it is obtained using husk pits in sandy soils. Even the lowest $\mathrm{B} / \mathrm{C}$ ratio indicates that an individual coconut producer could make 1.77 rupees if he buries one rupee worth of husks in sandy soils.

Table $3 N P V$ and $B / C$ ratios (in parenthesis) of different moisture conservation measures

\begin{tabular}{|c|c|c|c|c|}
\hline \multirow{2}{*}{$\begin{array}{l}\text { Interest } \\
\text { Rate }\end{array}$} & \multicolumn{2}{|c|}{$\begin{array}{l}\text { Lateritic Soil } \\
\text { (Coir dust) }\end{array}$} & \multicolumn{2}{|c|}{$\begin{array}{l}\text { Sandy Soil } \\
\text { (Husk) }\end{array}$} \\
\hline & $\begin{array}{l}\text { Financial } \\
\text { Analyses }\end{array}$ & $\begin{array}{l}\text { Economic } \\
\text { Analyses }\end{array}$ & $\begin{array}{l}\text { Financial } \\
\text { Analyses }\end{array}$ & $\begin{array}{r}\text { Economic } \\
\text { Analyses }\end{array}$ \\
\hline $10 \%$ & $\begin{array}{c}8935.66 \\
(5.85)\end{array}$ & $\begin{array}{c}14782.12 \\
(9.57)\end{array}$ & $\begin{array}{c}5869.92 \\
(2.27)\end{array}$ & $\begin{array}{c}12703.65 \\
(3.37)\end{array}$ \\
\hline $15 \%$ & $\begin{array}{c}6499.10 \\
(4.77)\end{array}$ & $\begin{array}{r}11187.83 \\
\therefore \quad(7.91)\end{array}$ & $\begin{array}{r}4138.51 \\
(1.94)\end{array}$ & $\begin{array}{c}9815.44 \\
(2.92)\end{array}$ \\
\hline $18 \%$ & $\begin{array}{r}5384.85 \\
(4.24)\end{array}$ & $\begin{array}{r}9518.15 \\
(7.09)\end{array}$ & $\begin{array}{c}3309.26 \\
(1.77)\end{array}$ & $\begin{array}{c}8421.53 \\
(2.69)\end{array}$ \\
\hline
\end{tabular}

The calculated NPV reconfirms the above results having positive values for all treatments under different discount rates: As expected, at the lowest discount rate the highest returns for both coir dust and coconut husks placement trials were obtained i.e. 
NPV Rs.8935.66 and Rs. 5869.92 for treatments of coir dust and coconut husks respectively. The lowest NPV s (Rs. 5384.85 and Rs.3309.26) were estimated respectively for coir dust and coconut husks at the highest discount rate of $18 \%$. Based on the evidence available it is clear that, regardless of the soils lateritic or sandy, the materials used husks or coir dust, the CRI recommended soil moisture conservation methods are economically acceptable on an individual coconut producer's view point. Therefore, coconut growers can adopt the soil maisture conservation methods recommended by the CRI, with confidence.

In this analysis however, the uncertainty associated with prices, yields or costs were not included. The considered values for the above parameters are presented in Table 2. It is clear that those figures (i.e. coconut price, labour wages etc) would vary over time. Therefore, possible worst scenarios such as reduction in income from coconut (for any reason due to reduction in yield or prices) by $10 \%$ and $20 \%$, increase in cost by $10 \%$ and $20 \%$ considered for the sensitivity analyses. The results of the sensitivity analysis are presented in Table 4 and 5 for lateritic and sandy soils respectively. Information presented in Table 4 and 5 indicates that even under the worst scenario, decrease in income from coconut by $20 \%$, investment on soil moisture conservation using coir dust and coconut husks, still gives B/C ratios of 2.14 and 1.15 for lateritic and sandy soils respectively. All the other scenarios provide much higher NPV and B/C ratios. This concludes that the CRI recommendations on soil moisture conservation are quite stable and sound and the economic investment propositions under the analyzed conditions are acceptable.

In order to examine the importance of soil moisture conservation in coconut lands using coconut husk and coir dust, economic (not financial) feasibility of the CRI recommendations was also investigated in national view point. Although the same data can be used for economic analyses as used for financial analyses certain transformations must to be made to reflect the social or national interest (Ananthacumaraswamy et al., 1985). In this study, to perform the economic analyses, cost of labour was valued as $80 \%$ of the market wage rates. This under valuation is justified due to imperfections in the labour market in the country. The cost of transport however, valued as $120 \%$ of the market price, because it involves fuel importation to the country. The other adjustment was made in valuing the husks and coir dust. Full market value of those materials were taken in economic analyses where as in financial analyses only $50 \%$ of the market values were taken. As husks and coir dust are not always purchased from the market such lower value was considered in financial analyses.

In a similar manner to transform the bènefits from soil moisture conservation for economic analyses incremental coconut yields were valued at the f.o.b. price. This is because coconut is an export crop and in the national view point incremental yield has a much higher value than the simple coconut market of coconut in the study area. Further, the subsidies given for soil moisture conservation were not included into the benefit stream in the economic analyses. This exclusion is necessary because subsidy is a transfer payment which does not have a real economic value in terms of national accounts. 
Table 4. Results of the sensitivity analysis under different scenarios for lateritic soils

\begin{tabular}{|c|c|c|c|c|c|c|c|c|c|c|c|}
\hline \multirow[t]{2}{*}{ Scenario } & \multirow[t]{2}{*}{$\begin{array}{l}\text { Interest } \\
\text { rate }\end{array}$} & \multicolumn{2}{|c|}{$\begin{array}{l}\text { Calculated using } \\
\text { expt. data }\end{array}$} & \multicolumn{2}{|c|}{$\begin{array}{l}\text { If yield decrease } \\
\text { by } 10 \%\end{array}$} & \multicolumn{2}{|c|}{$\begin{array}{l}\text { If yield decrease } \\
\text { by } 20 \%\end{array}$} & \multicolumn{2}{|c|}{$\begin{array}{l}\text { If cost increase } \\
\text { by } 10 \%\end{array}$} & \multicolumn{2}{|c|}{$\begin{array}{l}\text { If cost increase } \\
\text { by } 20 \%\end{array}$} \\
\hline & & $\mathrm{B} / \mathrm{C}$ & NPV & $B / C$ & NPV & $\mathrm{B} / \mathrm{C}$ & NPV & $\mathrm{B} / \mathrm{C}$ & NPV & $\mathrm{B} / \mathrm{C}$ & NPV \\
\hline & & & & & & & & & & $\cdot$ & \\
\hline $\begin{array}{l}\text { Scenario i } \\
\text { (for full } \\
\text { benefits) }\end{array}$ & $\begin{array}{l}10 \% \\
15 \% \\
18 \%\end{array}$ & $\begin{array}{l}5.85 \\
4.77 \\
4.24\end{array}$ & $\begin{array}{l}8935.66 \\
6499.10 \\
5384.85\end{array}$ & $\begin{array}{l}5.27 \\
4.29 \\
3.82\end{array}$ & $\begin{array}{l}7858.04 \\
5676.94 \\
4680.45\end{array}$ & $\begin{array}{l}4.68 \\
3.81 \\
3.4\end{array}$ & $\begin{array}{l}6760.41 \\
4854.78 \\
3976.05\end{array}$ & $\begin{array}{l}5.32 \\
4.34 \\
3.86\end{array}$ & $\begin{array}{l}8751.60 \\
6326.85 \\
5218.93\end{array}$ & $\begin{array}{l}4.88 \\
3.98 \\
3.54\end{array}$ & $\begin{array}{l}8567.54 \\
6154.60 \\
5053.02\end{array}$ \\
\hline $\begin{array}{l}\text { Scenario ii } \\
\text { (assuming } \\
\text { benefits } \\
\text { last only } \\
\text { six years) }\end{array}$ & $\begin{array}{l}10 \% \\
15 \% \\
18 \%\end{array}$ & $\begin{array}{l}3.46 \\
2.94 \\
2.67\end{array}$ & $\begin{array}{l}4296.38 \\
3207.16 \\
2685.53\end{array}$ & $\begin{array}{l}3.11 \\
2.64 \\
2.41\end{array}$ & $\begin{array}{l}3692.03 \\
2720.81 \\
2256.49\end{array}$ & $\begin{array}{l}2.77 \\
2.35 \\
2.14\end{array}$ & $\begin{array}{l}3087.68 \\
2234.47 \\
1827.45\end{array}$ & $\begin{array}{l}3.14 \\
2.66 \\
2.43\end{array}$ & $\begin{array}{l}4121.67 \\
3041.53 \\
2525.05\end{array}$ & $\begin{array}{l}2.88 \\
2.45 \\
2.23\end{array}$ & $\begin{array}{l}3946.96 \\
2875.90 \\
2364.56\end{array}$ \\
\hline
\end{tabular}

Table 5. Results of the sensitivity analysis under different scenarios for sandy soil

\begin{tabular}{|c|c|c|c|c|c|c|c|c|c|c|c|}
\hline \multirow[t]{2}{*}{ Scenario } & \multirow[t]{2}{*}{$\begin{array}{l}\text { Interest } \\
\text { rate }\end{array}$} & \multicolumn{2}{|c|}{$\begin{array}{l}\text { Calculated using } \\
\text { expt. data }\end{array}$} & \multicolumn{2}{|c|}{$\begin{array}{l}\text { If yield decrease } \\
\text { by } 10 \%\end{array}$} & \multicolumn{2}{|c|}{$\begin{array}{l}\text { If yield decrease } \\
\text { by } 20 \%\end{array}$} & \multicolumn{2}{|c|}{$\begin{array}{r}\text { If cost increase } \\
\text { by } 10 \%\end{array}$} & \multicolumn{2}{|c|}{$\begin{array}{r}\text { If cost increase } \\
\text { by } 20 \%\end{array}$} \\
\hline & & $\mathrm{B} / \mathrm{C}$ & NPV & $\mathrm{B} / \mathrm{C}$ & NPV & $\mathrm{B} / \mathrm{C}$ & NPV & $\mathrm{B} / \mathrm{C}$ & NPV & $\mathbf{B} / \mathbf{C}$ & NPV \\
\hline $\begin{array}{l}\text { Scenario i } \\
\text { (for full } \\
\text { benefits) }\end{array}$ & $\begin{array}{l}10 \% \\
15 \% \\
18 \%\end{array}$ & $\begin{array}{l}2.27 \\
1.94 \\
1.77\end{array}$ & $\begin{array}{l}5869.92 \\
4138.51 \\
3309.26\end{array}$ & $\begin{array}{l}2.04 \\
1.74 \\
1.59\end{array}$ & $\begin{array}{l}4812.77 \\
3272.19 \\
2548.59\end{array}$ & $\begin{array}{l}1.81 \\
1.55 \\
1.42\end{array}$ & $\begin{array}{l}3763.63 \\
2418.82 \\
1789.77\end{array}$ & $\begin{array}{l}2.06 \\
1.76 \\
1.61\end{array}$ & $\begin{array}{l}5398.96 \\
3684.74 \\
2879.33\end{array}$ & $\begin{array}{l}1.89 \\
1.61 \\
1.48\end{array}$ & $\begin{array}{l}4936.01 \\
3243.93 \\
2451.25\end{array}$ \\
\hline $\begin{array}{l}\text { Scenario ii } \\
\text { (assuming } \\
\text { benefits } \\
\text { last only } \\
\text { six years) }\end{array}$ & $\begin{array}{l}10 \% \\
15 \% \\
18 \%\end{array}$ & $\begin{array}{l}1.76 \\
1.55 \\
1.44\end{array}$ & $\begin{array}{l}3486.52 \\
2409.66 \\
1886.08\end{array}$ & $\begin{array}{l}1.58 \\
1.39 \\
1.30\end{array}$ & $\begin{array}{l}2678.36 \\
1730.30 \\
1271.38\end{array}$ & $\begin{array}{l}1.41 \\
1.24 \\
1.15\end{array}$ & $\begin{array}{c}1870.14 \\
1050.95 \\
656.69\end{array}$ & $\begin{array}{l}1.60 \\
1.41 \\
1.31\end{array}$ & $\begin{array}{l}3027.02 \\
1971.27 \\
1559.99\end{array}$ & $\begin{array}{l}1.47 \\
1.29 \\
1.20\end{array}$ & $\begin{array}{l}2567.46 \\
1532.88 \\
1033.91\end{array}$ \\
\hline
\end{tabular}


Results of the economic analysis are presented in Table 3. Only the base scenario was analyzed in this study. That is because often $10 \%$ discount rate is used in Sri Lanka for economic analyses and risk is not a-major concern as a whole society as it is very important to an individual coconut producer. Calculated B/C ratios as well as NPV $s$ indicate that the CRI recommended moisture conservation measures are economically viable.

\section{CONCLUSION}

The Benefit-Cost ratios and Net Present Values computed for different recommendations made by the CRI on soil moisture conservation indicate that all the recommendations can be considered as financially well sound and economical|y acceptable. Therefore, soil moisture conservation efforts in coconut production using coconut husks and coir dust are viable investments. Calculated Benefit-Cost ratios in this study indicate the high returns to the private investor, investing his money to conserve soil moisture. When one considers these investments on social or national view point still they are acceptable and the country is better off promoting such moisture conservation activities in coconut lands.

In this study total economic value of benefits and costs of the CRI recommendations have not been considered. However, based on the findings of the economic analysis, soil moisture conservation can be recommended on social view point too. Further, soil moisture conservation in coconut lands provides many other environmental and social (ie. protection of watershed, reduction of soil erosion, increase the income from coconut cultivation and provide more employment opportunities) benefits. When such benefits are also taken into account, these recommendations would be socially and environmentally more appealing to the individuals as well as to the country.

Based on the analyses performed in this study, high returns are possible from the investments. Materials used for moisture conservation practices viz. coconut husks and coir dust however, are not available in majority of coconut small holdings in Sri Lanka. Substantial cost is therefore, incurred in transporting these materials to their lands and this appears be a serious constraint. A strategy to overcome such initial capital constraints may be needed in the future to popularize moisture conservation activities.

\section{LIMITATIONS OF THE STUDY}

There are several limitations to this study. This wbole analysis is based on two experimental trials conducted by the Agronomy Division of the CRI. Both experiments were conducted concurrently in two locations and whether similar results would be applicable to the whole country at any time are not known. Hence, making use of information for generalization must be_done-very-carefully.

Before recommending any investment opportunity as a viable economic venture, one should consider the other alternative economic ventures available to the investor to use 
his money in a profitable manner. The researchers of this study however, have not looked into the possible alternative investment opportunities to a coconut producer, instead of soil moisture conservation in his coconut land.

Another limitation of this study is related to the length of the effective period of soil moisture conservation used for the analyses. For example, these experiments were set up in 1981 and 1982 for lateritic and sandy soils, respectively. However, untill 1984 the data collection work has not commenced. Therefore, the complete benefits from the effort on moisture conservation would not have been taken into account in this analyses.

- This problem, however, is not serious, because with the full period of data the results would have been even more attractive.

This expost analysis was carried out using past factor-product prices. However, the results of the present analysis subject to change with rapidly changing factor-product prices. Therefore, analysis has to be regularly updated with changed factor-product prices to provide latest information with regard to the economics of soil moisture conservation.

\section{ACKNOWLEDGEMENTS}

Our sincere thanks are due to $\operatorname{Dr} R$ Mahindapala, former Director, Coconut Research Institute of Sri Lanka (CRISL), for providing facilities and encouragement. Assistance of Dr M de S Liyanage, former Head, Agronomy Division, CRISL, by providing preliminary data is gratefully acknowledged. We also wish to thank $\mathrm{Dr}$ Samad, Mr A S Ranatunge, Drs D N S Fernando and R R A Peiris and Mr K B Dassanayake for their valuable comments. Work of Mr Liyanagama by providing relevant information is appreciated. Thanks are also due to Mr S D J N Subasinghe for his part in data collection.

\section{REFERENCES}

Abeywardena, V. (1968). Forecasting coconut crops using rainfall data: A preliminary study. Ceylon Cocon. Q., 19, 161-76.

Ananthacumaraswamy, A., Herath, H.M.G. and llangatilake, S. G. (1985). Economic feasibility of trickle irrigation in tea: some preliminary results. S. L. J. Tea Sci. 54 (2)., 84-90.

Anon. (1990). Soil and moisture conservation in coconut lands. Advisory Circular No. A7. Coconut Research Institute of Sri Lanka.

Gittinger, J.P. (1982). Economic analysis of agricultural projects. The Johns Hopkins University Press.

Liyanage, M. de. S., Jayasekera, K. S. and Dias, M. N. (1993). Effects of application of coconut husk and coir dust on the yield of coconut. Cocos, 9, 15-22. 
Peiris, T.S.G. and Peiris, R.R.A. (1991-1993). Effects of bimonthly rainfall on coconut yield in the low country intermediate zone (IL $)$ of Sri Lanka. Cocos, 9, 1-11.

Rognon, F. and Delbosc, G. (1990). Personal communication. Institut de Recherches pour les Huiles et Oleagineux. Paris.

Shanmugam, K. S. (1970). Coconut husk - Best to bury.. Coconut bulletin, 1 (5)., 3-6. 